\title{
Intraocular lenses and clinical treatment in paediatric cataract
}

\author{
Lentes intraoculares e tratamento \\ clínico na catarata pediátrica
}

Camila Ribeiro Koch Pena ${ }^{1}$, Priscilla Almeida Jorge ${ }^{2}$, Newton Kara-Junior ${ }^{2}$

\begin{abstract}
Pediatric cataract is the most common treatable cause of blindness in children. Prevalence, etiology and morphology vary with the socioeconomic development. The treatment goal is to reduce amblyopia, being difficult management especially in unilateral cases. The decision on aphakia or primary intraocular lens should be individualized as well as correction with contact lens or spectacles. The intraocular lens single-piece hydrophobic acrylic are the most implanted in children and the preferably is in the capsular bag. The Sanders-Retzlaff-Kraff theoretic (SRK/T) stressing that is described as more predictable, following Holladay I and SRK II and the recommendation is to under correction +6.0 or +8.0 dioptrias expecting the growth of the eye. The posterior capsule opacity is the most frequent complication and varies with the material choice of the lens. Glaucoma is the most serious postoperative complication and depends on the timing of the surgery, primary lens implantation and time of post surgical follow-up. The adherence to occlusion therapy with patching is critical to the visual prognosis and is determined by the child's age and laterality of the cataract. There was significant improvement in the surgery and in IOLs, however the final visual prognosis is still not desirable.
\end{abstract}

Keywords: Cataract/congenital; Cataract/etiology; Aphakia/surgery; Contact lenses; Lenses intraocular

\section{RESUMO}

A catarata pediátrica é a causa mais comum de cegueira tratável em crianças. Prevalência, etiologia e morfologia variam conforme o desenvolvimento sócioeconômico. O tratamento tem como objetivo diminuir a ambliopia, sendo de difícil manejo principalmente em casos unilaterais. A decisão sobre afacia ou implante primário de lente intraocular deve ser individualizado, assim como a correção com lente de contato ou óculos. As lentes intraoculares acrílicas hidrofóbicas de peça única são as mais implantadas em crianças com preferência de implante no saco capsular. A fórmula biométrica Sanders-Retzlaff-Krafftheoretic (SRK/T) é a mais precisa em pacientes pediátricos, seguida de Holladay I e SRK II, com recomendação de sob correção de +6 a +8.0 dioptrias, devido ao esperado crescimento rápido do globo ocular. A opacidade de cápsula posterior é a complicação mais frequente e varia com o material da lente a ser implantada e o glaucoma é a complicação pós-operatória mais grave e depende da idade da criança na cirurgia, implante primário de LIOs e da duração do acompanhamento pós-cirúrgico. A adesão ao tratamento oclusivo é fundamental para o prognóstico visual, sendo determinado de acordo com a idade da criança e a lateralidade da catarata. Mesmo com a melhora do tratamento cirúrgico e das lentes intraoculares o prognóstico visual final ainda não é o desejável.

Descritores: Catarata/congênito; Catarata/etiologia; Afacia/cirurgia; Lentes de contato; Lentes intraoculares

\footnotetext{
1 Instituto Brasileiro de Prevenção à Cegueira, Hospital Humberto Castro Lima, Salvador (BA), Brazil;

${ }^{2}$ Universidade de São Paulo (USP), São Paulo (SP), Brazil.
}

The authors declare no conflicts of interest 


\section{INTRODUCTION}

B lindness in children is a high-priority goal of the World Health Organization until 2020. In 1992, dates showed 1.5 million cases of childhood blindness in the world, in 2002 around 1.3 million and in 2010 around 1.4 million $^{(1,2)}$. The literature reports about $75 \%$ of avoidable blindness in children in the world, and $30 \%$ of them are due to Pediatric Cataract $(\mathrm{PC})^{(2)}$. Other important causes are refractive error, corneal opacities and retinopathy of prematurity ${ }^{(3)}$. Furthermore, socioeconomic development influence in the prevalence and etiology of PC. More than $85 \%$ of blind children live in Africa, Asia and Latin America ${ }^{(4)}$. In Brazil, the prevalence of low vision due to PC is still high, 5.5 to $12 \%$ of the patients ${ }^{(5)}$. It is known about the difficulty in obtaining accurate prevalence data on blindness in children due to very large samples population-based, besides the high cost, demands trained professionals and specific equipment.

The final goal of PC is successful visual rehabilitation. However, the controversy over the best correction of aphakia resulting from cataract surgery and primary intraocular lens (IOL) implantation, especially in newborns, remains under study. The purpose of this review is to report the prevalence causes, and treatment of pediatric cataract.

\section{Development}

\section{Morphology, Etiology and Clinical Findings}

The classification of PC depends on morphological analysis of lens opacity, its etiology and time of emergence.

The morphological types are according to the location of the lens opacity. They are Polar, Zonular, Coronary, Total (white), Membranous and Persistent Fetal Vasculature (PFV). The Zonular is the most common and according to the location may have subtypes: Nuclear, Lamellar, Capsule Plaque and Sutural ${ }^{(3)}$. Often there is an association between the subtypes. Most of the studies the Nuclear is the most common varying from 10 to $54 \%$, followed by lamellar. Usually nuclear is non progressive and almost all had an association with posterior capsule plaque ${ }^{(6,7)}$.

There is a socioeconomic influence in the other etiologies and morphology. Retrospective studies in developing countries asserted congenital infections, especially Rubella in the first trimester of pregnancy as one of the most prevalent etiologies and total cataract as one of the most common morphologies found, opposing the rarity in developed countries ${ }^{(8)}$. The vaccination campaigns against rubella have been reduced its prevalence( ${ }^{(2)}$. Others intrauterine infections (toxoplasmosis, herpes, syphilis, varicella, cytomegalic), birth dates (prematurity and low birth weight), syndromes (Down, Turner, Lowe, Hallermann-StreiffFrancois, Nance-Horan) and systemic diseases (galactosaemia, hypocalcaemia) are recognized as PC causes ${ }^{(3,6,7)}$. As regards etiology more than $50 \%$ of cases are idiopathic and one third of cases are hereditary, most of them autosomal dominant. ${ }^{(3,5,7,9)}$ Nuclear cataract have inheritance in $30-50 \%$ and lamellar commonly have pattern of inheritance too ${ }^{(3,7,8)}$.

Chronological classification depends on the time onset of the opacity. Congenital Cataract (CC) when detected before three months of life, Infantile Cataract (IC) when detected after three months and PC which includes all types. Trauma is the major cause of acquired cataracts in infants, however, traumatic is a type of cataract with management, implications and different expectations from CC. ${ }^{(7)}$ Most of the available studies affirm that $57-81 \%$ of PC are bilateral and is associated with systemic disorders or hereditary factors ${ }^{(7,9)}$. Available studies demonstrated PFV in $94-100 \%$ of eyes with unilateral CC, and it may have association with microphthalmia, aniridia, iris coloboma and lens coloboma ${ }^{(6,8)}$. Another peculiarity is its association with strabismus, nystagmus and fixation instabilities. The esotropia is found more and will generally follow deprivation amblyopia. The nystagmus is an indicator that vision is affected significantly. The importance of recognizing these signs is due to the fact that they were related to visual prognosis ${ }^{(4,10)}$.

\section{Decision about the treatment}

The decision about the treatment in children with PC depends on extension of lens opacity, through of the examination of the red reflex, retinoscopy and biomicroscopy or using a handheld slitlamp when possible or undergoing examination under anesthesia if necessary ${ }^{(3,4)}$. The red reflex in newborn detect early suspects of CC and has a low cost, reasons that made it mandatory in many hospitals ${ }^{(11)}$. The $\mathrm{CC}$ without risk to amblyopia shouldn't be an indication for surgery. Monitoring is preferred, in addition using mydriatic drops, occlusion of the dominant eye and postponing surgery to avoid surgical complications. The presence of dense opacities with more than $3 \mathrm{~mm}$ in diameter in the center of the lens brings low vision and should be removed $\mathrm{d}^{(3,7,12)}$. The ideal is to perform surgery between 1-4 months of life. Before 4 weeks risks outweigh the benefits ${ }^{(13)}$. Glaucoma is the most serious complication, the sooner the surgery the higher the risk, besides, the calculation of biometrics is more prone to errors and inflammation is more frequent. ${ }^{(3,7,9)}$ Thus, after 4 weeks of life surgery should be performed and the vision can be developed in the best possible way. At birth the visual system is immature and is still developing in early months of life. The newborn has poor fixation, very limited ability to discriminate colors, limited visual fields and an estimated visual acuity between 20/200 and 20/400 ${ }^{(14)}$. During the growth, the acuity reaches the healthy adult standard of 20/20 at 6 months. The development of the visual stimulus depends on the integrity of a complex network which includes retina, optic nerve, optic radiations, visual pathway and visual cortex. The development of the cortex depends on the phenomenon called plasticity, manipulated by changes in stimuli, for example presence of CC or treatment using patching ${ }^{(12)}$. In general the images provided by the better eye will be recorded. Knowing this, studies recommend early surgery with the aim of reducing the risk of amblyopia, principally in unilateral $\mathrm{IC}^{(12,14)}$.

\section{Surgery and complications}

The child's eye has some details that make technically more difficult the cataract surgery than adults ${ }^{(3,7,15)}$. The anterior capsule is more elastic, the vitreous pressure is larger, the sclera is thinner, small pupil is often and the hydrodissection should be more careful in posterior polar because in $40 \%$ of the surgeries it may be stuck in the posterior capsule ${ }^{(3,16)}$.

The femtosecond laser in infants began to be realized with success helping principally in the capsulotomy, with a specific diameter without risk for capsular tears. The difference between adults and children is the size of the eye which is impossible to accommodate the laser's interface. So it is necessary in children create a small lateral cantholysis of less than $2 \mathrm{~mm}$ to realize the 
procedure $^{(17)}$. Probably in the future the laser will be a more consolidated step in children's cataract surgery.

Posterior capsule opacification (PCO) is an expected complication, requiring additional treatment with Neodymium YAG-laser or intraocular reoperation in order to recovery the optical transparency because of the risk of amblyopia. To avoid this postoperative complication, some surgeons perform a posterior capsulotomy with anterior vitrectomy ${ }^{(3,5)}$. PCO incidence varies depending on IOL materials ${ }^{(18)}$. Reports show that hydrophobic acrylic IOLs apparently have more PCO than polymethyl methacrylate (PMMA) IOLs, even then, the prevalence is high, reaching $50 \%^{(18,19)}$. Glaucoma is the most severe complication after IC surgery. It may occur several years after primary surgery, being more frequent the development around 3 years of age and needs long-term follow-up ${ }^{(20)}$. The prevalence varies from $3.5 \%$ to $58 \%$ and the exact etiology is still unknown ${ }^{(13,21)}$. This large variation in prevalence of glaucoma may be related to the length of time of post operative follow-up of children ranging in the studies, since the risk continues to rise with time ${ }^{(20,21)}$. Bilateral cataract is associated with a higher risk of glaucoma ${ }^{(13,20)}$. Furthermore, the literature is contradictory on primary IOL implantation and glaucoma development. The theoretical explanation for the IOL to prevent glaucoma is to avoid the vitreous contacting the trabecular meshwork. On the other hand intact posterior capsule may be associated with a lower risk of development glaucoma ${ }^{(22)}$.

Other less frequent adverse events can occur after PC surgery, such as pupillary membranes, corectopia, phimosis of the anterior capsule, lens reproliferation, vitreous hemorrhage, retinal detachment, endophthalmitis, phithisis bulbi, corneal abrasion, corneal edema, dilated pupil and capsular phimosis ${ }^{(15,23)}$.

\section{IOLs}

IOLs implantation in children after two years old is accepted by most pediatric surgeons. In the 1980s, the introduction of PMMA IOLs and vitrectomy instrumentation got an improvement in surgical results, and the introduction of hydrophobic acrylic IOLs in 1990's made it better ${ }^{(24)}$. Even with increasing costs, the hydrophobic acrylic single-piece lens implanted in the capsular bag became the favorite among surgeons, due to the possibility to introduce the IOLs in small incision, with less trauma and less $\mathrm{PCO}^{(24)}$.

Three piece IOLs can be deformed in small eyes and occlusion the pupil, but are indicated for sulcus fixation. Silicone and hydrophilic acrylic IOLs are not the first choice for children, because more PCO and capsule contraction was found respectively. However some studies show good results with hydrophilic acrylic IOLs compared to PMMA IOLs ${ }^{(25)}$.

From birth to maturity, the eye increases three times its size. One third of the eye's growth in diameter occurs in the first year of life. The axial length (AL) is extremely short, most of them less than $20 \mathrm{~mm}$ and the refractive power of the cornea is high, about 51 dioptries (D), consequently the prediction error in IOL calculation is expected. Every $1 \mathrm{~mm}$ of increase in ocular length results in approximately $2.50 \mathrm{D}$ of myopic shift. An axial length measurement error is increased at 4 to $14 \mathrm{D} / \mathrm{mm}$ in children compared with 3 to $4 \mathrm{D} / \mathrm{mm}$ error in adults ${ }^{(26)}$. Some reports suggest under correction in 20-30\%, hyperopia of +6.0 or $+8.0 \mathrm{D}$, expecting this growth of the eye, especially in bilateral cataract and correction with contact lenses in the first months after the surgery ${ }^{(27,28)}$. AL measurements are possible under anesthesia with A-scan ultrasonography, being contact or immersion with equivalent results ${ }^{(29,30)}$. With respect to biometric formulas, they can be used the same as in adults, stressing that Sanders-RetzlaffKraff theoretic (SRK/T) is described as more predictable, following Holladay I and SRK II ${ }^{(24,28,31)}$

There is no agreement about the best time for surgery and IOL implantation. It is advisable to leave aphakia infants less than seven months of life, especially for families who can afford and properly perform the treatment with contact lens ${ }^{(32)}$. However, we expect complications in the eyes of these children to be subjected to secondary implant later and this should be weighed. The primary implant is an option in cases where there is risk of decreasing visual acuity of the child for inappropriate use of contact lens. According to some studies, the correction with primary IOL implantation unilateral results in improved visual acuity, improved binocular vision outcome, but higher rate of complications requiring reoperation ${ }^{(5)}$. Recently, a multicenter clinical trial compared cataract surgery in children less than seven months of age with unilateral $\mathrm{CC}$ with and without IOL implantation following in the first 5 years. The long-term monitoring showed no statistical difference in the outcome of visual acuity between groups ${ }^{(33)}$.

\section{Aphakia rehabilitation}

Beyond the diagnostic difficulty, intrasurgical complications, decisions on IOL implantation and postoperative adverse events, the IC requires a rigorous treatment of visual correction and refraction requires more attention, preferably with pediatric ophthalmologist, psychological monitoring and expert fitting of contact lens in children.

\section{Contact Lens/Spectacles}

The infantile aphakia visual rehabilitation is possible with contact lens (CL), soft (SE) or rigid gas permeable (RGP), or spectacles. The recommendation is CL in monocular aphakia and spectacles in bilateral aphakia, but the financial conditions and the family support must be taken into account. The literature shows some successful cases in monocular aphakia with spectables and patching and CL in bilateral aphakia and nystagmus $\mathrm{CC}^{(10,34)}$. The $\mathrm{CL}$ in children are harder to fit than in adults, but follow the same principles. The rapid growth of the eye during the first 18 months of life requires frequent monitoring ${ }^{(35)}$. At birth the horizontal corneal diameter (HCD) is about $10 \mathrm{~mm}$ in normal eyes and the corneal curvature between $47 \mathrm{D}(7.18 \mathrm{~mm})$ and $48.50 \mathrm{D}(6.96 \mathrm{~mm})$ and close to two years of age is approximately $43,5 \mathrm{D}$ and the HCD increases to $11,5 \mathrm{~mm}$ between 3 and 4 years old ${ }^{(36)}$.

The suggestion in newborns with a normal eye is to start with a specifically RGP designed for aphakia infants in flatter curve of the cornea (K), about 7.00 to $7.5 \mathrm{~mm}$ and increase frequently about every three months for the infant's first 12 months. The total diameter fitting in RGP depends on the infant's age; usually of $10.0 \mathrm{~mm}$, vary 8.3 to $11.2 \mathrm{~mm}$ and refraction $+26 \mathrm{D}$ to $+32 \mathrm{D}^{(35,37)}$. The $\mathrm{SE}$ about 2.5 to $3.0 \mathrm{~mm}$ larger than the horizontal visible iris diameter. Newborns should be overcorrected by about $+2,50$ to $+3,00 \mathrm{D}$ to focus them at this near viewing point correction at $50 \mathrm{~cm}$ and at 18 to 24 months of age should be reduced to $+1,00$ to $+1,50 \mathrm{D}$, when children starts to become more aware of distant objects and at 3 to 4 years should have appropriate distance correction, with the reading correction then incorporated into a pair of spectacles, usually bifocals or multifocal, to be used over the contact lenses ${ }^{(37)}$. The lens will be removed once a week in particular leaving it in solution. 
The silicone hydrogel SE is the type more fitting in pediatrics, is easy to fit, because it is a logical way without keratometry, very stable on the eye and has a good oxygen supply even in a high plus power ${ }^{(32)}$. On the other hand, it does not correct the significant corneal astigmatism, it is more difficult to insert by the parents and loss is not uncommon ${ }^{(35)}$. RGP is even more stable, able to correct for any corneal astigmatism, easier handling and some complications are less common, such as microbial keratitis, corneal vascularisation and pappillary conjunctivitis. However, RGP requires more medical expertise, is more prone to foreign bodies and more easily ejected. Apparently, there are no differences in visual acuity between SE and wearing $\operatorname{RGP}^{(38)}$.

\section{Secondary IOL implantation}

In the aphakic infants an elective secondary IOL implantation appears to provide a safe and effective alternative, like in some cases the inability to wear contact lens successfully. The secondary IOL implantation around 2 years in bilateral IC may show better visual prognosis than early primary IOL implantation and can contribute to lowering glaucoma incidence ${ }^{(39)}$. The IOL can be inserted in the capsular bag or in the ciliary sulcus, with/without iris or scleral fixation, depending on the situation ${ }^{(40)}$. Possible complications should be taken into account, such as macular edema and elevated intraocular pressure $^{(15)}$.

\section{Ambliopy treatment}

The risk of amblyopia is greatest during the first year of life. The occlusion therapy with patching should be prescribed soon after the surgery in unilateral or bilateral cataract, around 2-4 weeks at the same time starting the most accurate refractive error correction possible in pseudophakic or aphakia either with spectacles or contact lens ${ }^{(3)}$. If none of these forms work, the choice in those cases is IOL secondary implantation. The period of use the treatment with patch has relation with the age of the patient $t^{(3,7,12)}$. Up to 12 months of life in infants that are left with unilateral aphakia, occlusion of the eye not operated for 1 hour daily is recommended and after, a half of awaking hours is indicated, that way forcing the brain to use the suppressed eye ${ }^{(33)}$. In bilateral cases if one eye is more amblyopic than the other the occlusion therapy is necessary and is important alternation the patching among the eyes. In general, the success of occlusion therapy for amblyopia will depend on the age of the patient, the degree of visual impairment and adherence to treatment ${ }^{(41)}$. The duration will depend on recovery of vision during the first decade of life. There must be careful monitoring, to avoid sensory deprivation amblyopia in the eye occluded. A recent study compared children with unilateral IC treatment with IOL implanted at the time of the surgery or corrected aphakia with contact lens showed incidence of nystagmus and fixation instabilities about $60 \%$ overall $^{(10)}$.

\section{Visual acuity}

Reports about visual results after cataract surgery in the children must have careful consideration when compared to each other, because the visual outcome depends on the age of the patient, type of cataract, laterality, the delay until surgery and visual rehabilitation treatment. The chance of amblyopia is higher in unilateral IC, dense lens, delayed surgery and irregular treatment with occlusion or contact lens/spectacle.
The best choice to measure the best corrected visual acuity in children is the Teller acuity card. It is accurate, is possible estimates of the VA in about 5 minutes and can be use with children starting at one month of age ${ }^{(42)}$. The Visual evoked potentials (VEP) is relatively simple and noninvasive but it is a time consuming procedure. The electrical activity in the brain is measured in response to stimulation of sight and should be indicated as a supplement in special cases ${ }^{(43)}$.

Reports shown in unilateral IC with or without IOL implantation underwent surgery before 1 year age, visual acuity about 40 to $50 \%$ with poor visual acuity $\leq 20 / 200$. The better vision around 20/32 the vast majority without primary IOL implantation ${ }^{(44)}$. Primary IOL implantation in bilateral CC implantation underwent surgery before 1 year of age mostly lies between $20 / 25$ to 20/100. Secondary IOL implantation around 2 years in bilateral CC implantation underwent surgery before 1 year age mostly lies between $20 / 100$ to $20 / 40$, the latter $40 \%$ of the children ${ }^{(45)}$. Almost all these children will be able to attend a normal school.

\section{Conclusions and recommendations}

IC is still a major cause of blindness in the world even with government investments. The prognosis is worse in congenital cataract with associated disorders or unilateral. The timing of surgery is critical, therefore the importance of the red reflex test at birth and forwarding to a reference center. The lens implant is consolidated starting from the age of two, however before this age it is questionable because the literature shows no statistical difference in visual acuity and a greater number of surgical interventions, especially until 12 months of life. Glaucoma is the worst complication and PCO the most common. All methods of visual acuity correction have their limitations and advantages, and the choice must be made individually. The suggestion is to delay IOL implantation if the families can manage contact lens care and expense. The long-term safety remains a consideration. Cataract surgery offers children with this condition the best chance for a full life.

\section{ReferenCes}

1. Resnikoff S, Pascolini D, Etya, Ale D, Kocur I, Pararajasegaram $\mathrm{R}$, et al. Global data on visual impairment in the year 2002.(Policy and Practice). Bull World Health Org. 2004;82(11):844-51.

2. Gogate P, Gilbert C, Zin A. Severe Visual Impairment and Blindness in Infants: Causes and Opportunities for Control. Middle East African Journal of Ophthalmology. 2011;18(2):109-14.

3. Zetterstrom C, Kugelberg M. Paediatric cataract surgery. Acta Ophthalmol Scand. 2007;85(7):698-710.

4. Lin H, Yang Y, Chen J, Zhong X, Liu Z, Lin Z, et al. Congenital cataract: prevalence and surgery age at Zhongshan Ophthalmic Center (ZOC). PLoS One. 2014;9(7):e101781.

5. Rezende MS, Souza SB, Dib O, Branzoni E, Ribeiro LE. Abordagem da catarata congênita: análise de série de casos.Rev Bras Oftalmol. 2008;67(1):32-8.

6. Wilson ME, Trivedi RH, Morrison DG, Lambert SR, Buckley EG, Plager DA, et al. The Infant Aphakia Treatment Study: evaluation of cataract morphology in eyes with monocular cataracts. J AAPOS. 2011;15(5):421-6.

7. Padilha M. Catarata. 2a ed. Rio de Janeiro: Cultura Médica; 2008. 634 p.

8. Tartarella MB, Britez-Colombi GF, Milhomem S, Lopes MC, Fortes Filho JB. Pediatric cataracts: clinical aspects, frequency of strabismus and chronological, etiological, and morphological features. Arq Bras Oftalmol. 2014;77(3):143-7. 
9. Haargaard B, Wohlfahrt J, Fledelius HC, Rosenberg T, Melbye M. A nationwide Danish study of 1027 cases of congenital/infantile cataracts: etiological and clinical classifications. Ophthalmology. 2004;111(12):2292-8.

10. Felius J, Busettini C, Lynn MJ, Hartmann EE, Lambert SR. Nystagmus and related fixation instabilities following extraction of unilateral infantile cataract in the Infant Aphakia Treatment Study (IATS). Invest Ophthalmol Vis Sci. 2014;55(8):5332-7.

11. Rodrigues AC, Prado RB, Miguel L. [Implementation of red reflex exam in children in the area of Botucatu Medical School Clinical Hospital-São Paulo, Brazil]. Arq Bras Oftalmol. 2012;75(5):337-40. Portuguese.

12. Taylor D, Wright K, Amaya L, Cassidy L, Nischal K, RussellEggitt I. Should we aggressively treat unilateral congenital cataracts? Br J Ophthalmol. 2001;85(9):1120-6.

13. Chen TC, Bhatia LS, Halpern EF, Walton DS. Risk factors for the development of aphakic glaucoma after congenital cataract surgery. Trans Am Ophthalmol Soc. 2006;104:241-51.

14. Wiesel TN, Hubel DH. Effects of visual deprivation on morphology and physiology of cells in the cats lateral geniculate body. $\mathrm{J}$ Neurophysiol. 1963;26:978-93.

15. Whitman MC, Vanderveen DK. Complications of pediatric cataract surgery. Semin Ophthalmol. 2014;29(5-6):414-20.

16. Kalantan H. Posterior polar cataract: A review. Saudi J Ophthalmol.26(1):41-9.

17. Dick HB, Schultz T. Femtosecond laser-assisted cataract surgery in infants. J Cataract Refract Surg. 2013;39(5):665-8.

18. Jorge Pde A, Jorge D, Ventura CV, Ventura BV, Lira W, Ventura MC, Santhiago MR, Kara-Junior N. Incidence of posterior capsule opacification following the implantation of a foldable hydrophilic acrylic intraocular lens: a 4 year follow-up study.Arq Bras Oftalmol. 2014;77(4):222-4.

19. Jorge Pde A, Jorge D, Ventura CV, Ventura BV, Lira W, Ventura MC, Werner L, Kara N Jr. Late opacification in hydrophilic acrylic intraocular lenses: analysis of 87 eyes in a random sample of 102 patients.J Cataract Refract Surg. 2013;39(3):403-7.

20. Urban B, Bakunowicz-Lazarczyk A. Aphakic glaucoma after congenital cataract surgery with and without intraocular lens implantation. Klin Oczna. 2010;112(4-6):105-7.

21. Plager DA, Lynn MJ, Buckley EG, Wilson ME, Lambert SR. Complications in the First 5 Years Following Cataract Surgery in Infants With and Without Intraocular Lens Implantation in the Infant Aphakia Treatment Study. Am J Ophthalmol. 2014;158(5):892-898.e2.

22. Michaelides M, Bunce C, Adams GG. Glaucoma following congenital cataract surgery-the role of early surgery and posterior capsulotomy. BMC Ophthalmol. 2007 Sep 11;7:13.

23. Jorge Pde A. Intraocular lens opacification. Rev Bras Oftalmol. 2014; 73(2):69-70.

24. Wilson ME, Jr., Trivedi RH, Buckley EG, Granet DB, Lambert SR, Plager DA, et al. ASCRS white paper. Hydrophobic acrylic intraocular lenses in children. J Cataract Refract Surg. 2007;33(11):1966-73.

25. Kleinmann G, Zaugg B, Apple DJ, Bleik J. Pediatric cataract surgery with hydrophilic acrylic intraocular lens. J AAPOS. 2013;17(4):367-70.

26. Eibschitz-Tsimhoni M, Tsimhoni O, Archer SM, Del Monte MA. Effect of axial length and keratometry measurement error on intraocular lens implant power prediction formulas in pediatric patients. J AAPOS. 2008;12(2):173-6.

27. Dahan E, Drusedau MU. Choice of lens and dioptric power in pediatric pseudophakia. J Cataract Refract Surg. 1997;23 Suppl 1:618-23.

28. VanderVeen DK, Nizam A, Lynn MJ, Bothun ED, McClatchey SK, Weakley DR, et al. Predictability of intraocular lens calculation and early refractive status: the Infant Aphakia Treatment Study. Arch Ophthalmol. 2012;130(3):293-9.
29. Hennessy MP, Franzco, Chan DG. Contact versus immersion biometry of axial length before cataract surgery. J Cataract Refract Surg. 2003;29(11):2195-8.

30. Ben-Zion I, Neely DE, Plager DA, Ofner S, Sprunger DT, Roberts GJ. Accuracy of IOL calculations in children: a comparison of immersion versus contact A-scan biometery. J AAPOS. 2008;12(5):440-4.

31. Kekunnaya R, Gupta A, Sachdeva V, Rao HL, Vaddavalli PK, Om Prakash V. Accuracy of intraocular lens power calculation formulae in children less than two years. Am J Ophthalmol. 2012;154(1):13-9.e2.

32. Efron $\mathrm{N}$, Hough T.Soft lens manufacture. In Efron $\mathrm{N}$, editor.Contact lens practice. Oxford: Butterworth-Heinemann; 2002.p. 85-93.

33. Lambert SR, Buckley EG, Drews-Botsch C, DuBois L, Hartmann E, Lynn MJ, et al. The infant aphakia treatment study:design and clinical measures at enrollment. Arch Ophthalmol.2010;128(1):21-7.

34. Woo M, Isenberg S, Spooner SN, Weissman BA. Long-term visual and ocular health outcomes of 2 sets of bilaterally aphakic siblings utilizing contact lens correction. Cont Lens Anterior Eye. 2013;36(4):207-11.

35. Lindsay RG, Chi JT. Contact lens management of infantile aphakia.Clin Exp Optom.2010;93(1):3 14.

36. Inagaki $Y$. The rapid change of corneal curvature in the neonatal period and infancy. Arch Ophthalmol. 1986;104(7):1026-7.

37. Ghanem C. Lentes de contato na criança. In: Série de Oftalmologia CBO. III. Rio de Janeiro: Guanabara Koogan; 2008. p. 277-91.

38. Russell B, Ward MA, Lynn M, Dubois L, Lambert SR. The infant aphakia treatment study contact lens experience: one-year outcomes. Eye Contact Lens. 2012;38(4):234-9.

39. Speeg-Schatz C, Flament J, Weissrock M. Congenital cataract extraction with primary aphakia and secondary intraocular lens implantation in the ciliary sulcus. J Cataract Refract Surg. 2005;31(4):750-6.

40. Secondary IOL implantation in aphakic children after early surgery for congenital cataracts. Vestn Oftalmol. 2014;130(4):5761.

41. Moore BD. Pediatric aphakic contact lens wear: rates of successful wear. J Pediatr Ophthalmol Strabismus. 1993;30(4):253-8.

42. Hall HL, Courage ML, Adams RJ. The predictive utility of the Teller acuity cards for assessing visual outcome in children with preterm birth and associated perinatal risks. Vision Res. 2000;40(15):2067-76.

43. Riddell PM, Ladenheim B, Mast J, Catalano T, Nobile R, Hainline L. Comparison of measures of visual acuity in infants: Teller acuity cards and sweep visual evoked potentials. Optom Vis Sci. 1997;74(9):702-7.

44. Lambert SR, Lynn MJ, Hartmann EE, DuBois L, Drews-Botsch C, Freedman SF, et al. Comparison of contact lens and intraocular lens correction of monocular aphakia during infancy: a randomized clinical trial of HOTV optotype acuity at age 4.5 years and clinical findings at age 5 years. JAMA Ophthalmol. 2014;132(6):676-82.

45. Kim DH, Kim JH, Kim SJ, Yu YS. Long-term results of bilateral congenital cataract treated with early cataract surgery, aphakic glasses and secondary IOL implantation. Acta Ophthalmol. 2012;90(3):231-6.

\section{Correspondente author:}

\section{Camila Ribeiro Koch Pena}

Rua Hilton Rodrigues $n^{\circ}$ 71, apto. 903 - Ed Torre Molinos,

Bairro Pituba

CEP 41830-630 - Salvador (BA), Brasil

Email:camila_koch@yahoo.com.br 